Gut, 1987, 28, S1, 139-141

\title{
Effect of prostaglandins on the adult rat stomach and intestine
}

\author{
F HALTER, A BAUMGARTNER, H R KOELZ, AND W H REINHART \\ From the Gastrointestinal Unit, Inselspital, 3010 Berne, Switzerland
}

Robert was the first to put forward the hypothesis that prostaglandins may act as trophic hormones ${ }^{12}$ in much the same way as gastrin has shown to be trophic to the gastric corpus. Cell kinetic studies performed by Johnson and Guthrie ${ }^{3}$ suggested that this trophic effect was very feeble and restricted to the duodenum. Histomorphometric studies carried out in our laboratories, however, revealed that in adult rats topical application of 5-100 $\mu \mathrm{g} / \mathrm{kg} \mathrm{16,16-dimethyl} \mathrm{prosta-}$ glandin $E_{2}$ (PGE2) every eight hours produces an impressive dose dependent increase in the height of the mucosa of the stomach as well as of the small intestine and to a lesser degree of the colon. ${ }^{4}$ Treatment with the high dose resulted in a thickening of the gastric mucosa macroscopically visible from the aspect of the mucosal ridge at the border between the forestomach and the corpus (Figure). The increase in height and width of the ridge was the result of the combined increase of the volume of stratified epithelium as well as of that of the lamina propria. Morphometric analysis of the glandular parts of the stomach revealed both cell hypertrophy and hyperplasia. The cells particularly affected both in the gastric corpus and the antrum were the surface and foveolar mucous cells. The numbers were increased by approximately $30 \%$ even with the low dose, while this amounted to almost $100 \%$ with the high dose. Neither the number nor the size of the parietal cells were significantly increased, however, an insignificant increase in both the cell numbers and cell size additively contributed to a significant increase of the total parietal cell volume. In the upper small bowel

Table Cell proliferation: comparison of various studies

\begin{tabular}{|c|c|c|c|c|}
\hline Author & Model & Treatment & Methods & Proliferation \\
\hline Johnson $^{3} 1976$ & rat & $\begin{array}{l}16,16-\mathrm{dm} \text { PGE2 } \\
200 \mu \mathrm{g} / \mathrm{kg} \text { tds } \\
3 \text { days }\end{array}$ & $\begin{array}{l}\text { 3H-T incub in vitro } \\
\mathrm{DPM} / \mu \mathrm{g} \text { DNA }\end{array}$ & $\begin{array}{l}\text { no effect in corpus } \\
\text { duodenum }\end{array}$ \\
\hline Reinhart $^{4} 1983$ & rat & $\begin{array}{l}16,16-\mathrm{dm} \text { PGE } 2 \\
100 \mu \mathrm{g} / \mathrm{kg} \text { tds ig } \\
3 \text { weeks }\end{array}$ & mitotic index & antrum \\
\hline Halter 1984 & rat & $\begin{array}{l}16,16-\mathrm{dm} \text { PGE2 } \\
25 \mu \mathrm{g} / \mathrm{kg} \text { tds ig, ip } \\
3 \text { weeks }\end{array}$ & $\begin{array}{l}\text { 3H-T ip, } \\
\text { labelling index }\end{array}$ & $\begin{array}{l}\text { ip: antrum } \\
\text { ig: corpus }\end{array}$ \\
\hline Uribe $^{6} 1986$ & rat & $\begin{array}{l}\text { 15,15-me PGE2 ig } \\
\text { dose? } \\
5 \text { days }\end{array}$ & $\begin{array}{l}\text { 3H-T ip } \\
\text { labelling index }\end{array}$ & antrum \\
\hline Dembinski' 1985 & rat & $\begin{array}{l}\text { PGE2 }(1 \mathrm{mg} / \mathrm{kg}) \\
15,15-\mathrm{dm} \text { PGF2a } \\
(1 \mathrm{mg} / \mathrm{kg}) \mathrm{tds} \\
2 \text { days }\end{array}$ & $\begin{array}{l}3 \mathrm{H}-\mathrm{T} \text { incub in vitro } \\
\mathrm{DPM} / \mu \mathrm{gDNA}\end{array}$ & $\begin{array}{l}\text { corpus } \\
\text { duodenum }\end{array}$ \\
\hline Fich $^{8} 1985$ & $\operatorname{man}$ & $\begin{array}{l}\text { misoprostol } \\
4 \text { weeks }\end{array}$ & $\begin{array}{l}3 \mathrm{H}-\mathrm{T} \text { incub in vitro } \\
\text { labelling index }\end{array}$ & $\begin{array}{l}\text { antrum } \\
\text { fundus }\end{array}$ \\
\hline Baumgartner ${ }^{9} 1986$ & rat & $\begin{array}{l}16,16-\mathrm{dm} \text { PGE2 } \\
100 \mu \mathrm{g} / \mathrm{kg} \text { ig } \\
8 \mathrm{~h} \text { after single dose }\end{array}$ & $\begin{array}{l}\text { 3H-T ip, } \\
\text { labelling index } \\
\text { and DPM } / \mu \mathrm{gDNA}\end{array}$ & antrum \\
\hline Tytgat $^{10} 1986$ & $\operatorname{man}$ & $\begin{array}{l}15,15-\mathrm{me} \text { PGE2 } \\
400 \mathrm{mg} \text { ig } \\
3 \text { months }\end{array}$ & $\begin{array}{l}3 \mathrm{H}-\mathrm{T} \text { incub in vitro } \\
\text { labelling index }\end{array}$ & $\begin{array}{l}\text { no effects in } \\
\text { corpus }+ \text { antrum }\end{array}$ \\
\hline
\end{tabular}



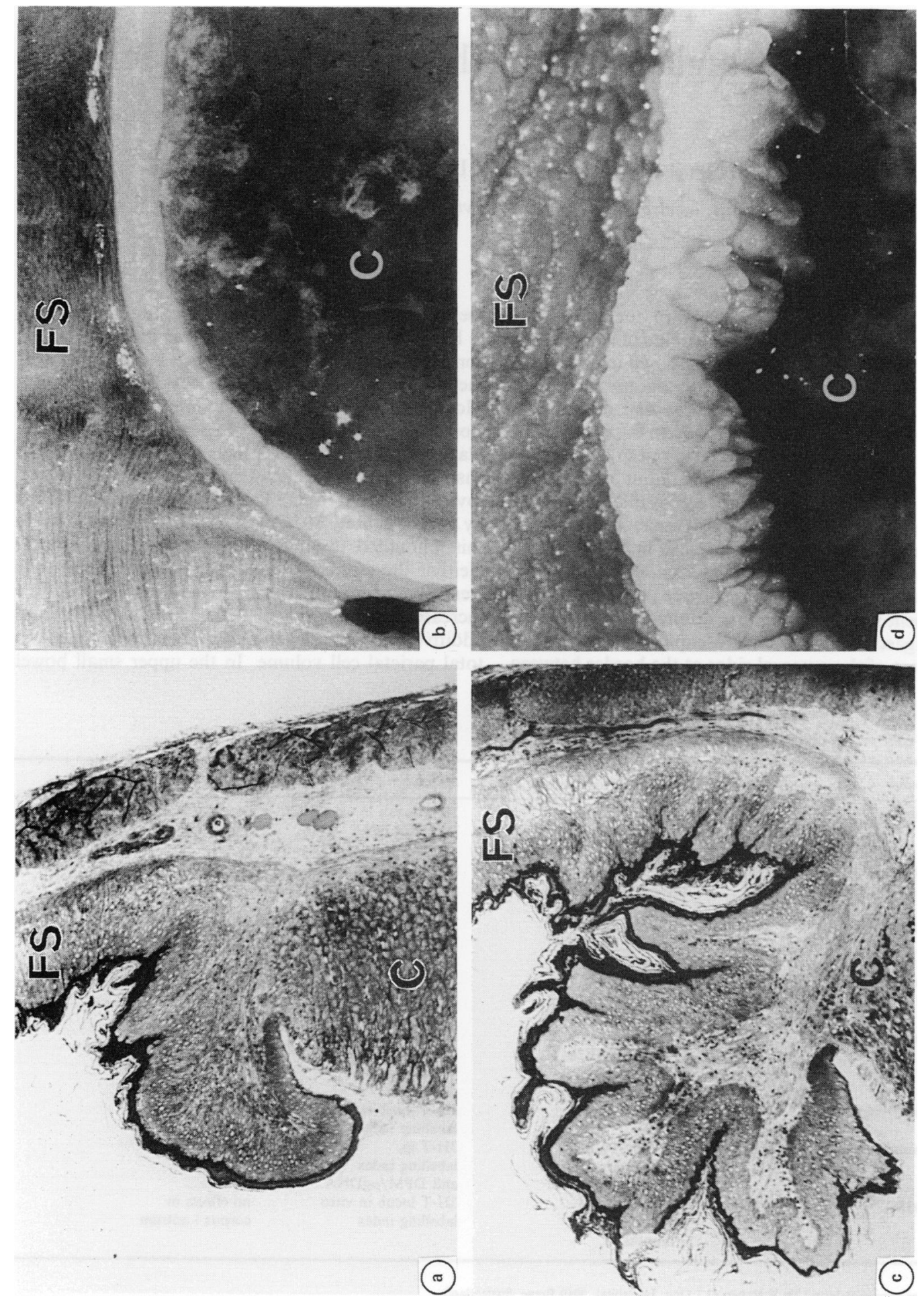

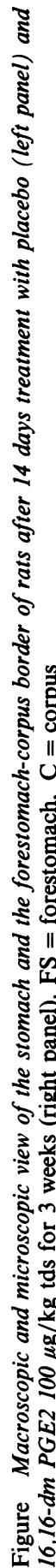

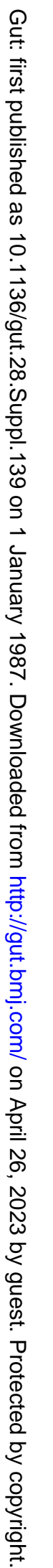


both the height of the villi and the depth of the crypts were significantly increased.

These results were confirmed subsequently by other authors using both natural prostaglandins $E_{2}$ as well as various analogues of prostaglandin $E_{1}$ and $E_{2}$ in experimental animals and man. ${ }^{6-810}$

Studies undertaken to evaluate the mechanisms of this trophic effect have yielded conflicting results (Table). Several reports show the slight increase in cell proliferation induced in the early treatment phase whereas cell renewal seems to be delayed during prolonged prostaglandin application. Of particular interest is the study of Uribe et $a l^{6}$ who found evidence that prostaglandins delay the clearance of labelled DNA from the corpus, antral, duodenal and jejunal mucosa suggesting an increase in the survival of glandular cells. A slight decrease in cell proliferation was observed also by $\mathrm{Fich}^{8}$ in duodenal ulcer patients treated for four weeks with the PGE analogue misoprostil, while a similar study with R 15 methyl $\mathrm{PGE}_{2}{ }^{10}$ revealed no difference in cell proliferation despite hyperplasia of the mucous cells of the gastric antrum. Differences in dosage and duration of treatment and the timing of cell proliferative studies may be responsible for these discrepancies. One may speculate that prostaglandin treatment initially stimulates production of new cells which then have a longer life cycle. This would result in a decrease in cell shedding and may as suggested by Uribe $e t a l^{6}$ in turn exert a negative feedback on cell reproduction. It is thus likely that both the initial increase in cell proliferation and the prolonged cell survival contribute to the increase in epithelial cell mass.

\section{References}

1 Robert A. An intestinal disease produced experimentally by a prostaglandin deficiency. Gastroenterology 1975; 69: 1045-7.

2 Robert A. Antisecretory, antiulcer, cytoprotective and diarrheogenic properties of prostaglandins. Adv Prostaglandin Thromboxane Res 1976; 2: 507-20.

3 Johnson LR, Guthrie B. Effect of cholecystokinin and 16,16-dimethyl prostaglandin $E_{2}$ on RNA and DNA of gastric duodenal mucosa. Gastroenterology 1976; 70: 59-65.

4 Reinhart, WH, Müller O, Halter F. Influence of longterm 16,16-dimethyl prostaglandin $\mathrm{E}_{2}$ treatment on the rat gastrointestinal mucosa. Gastroenterology 1983; 85: 1003-10.

5 Halter F, Meyrat P, Fritsche R, Müller O, Lentze MJ, Koelz HR. Both topical and systemic treatments with 16,16-dimethyl prostaglandin $\mathrm{E}_{2}$ are trophic to rat gastric mucosa. Scand J Gastroenterol 1984; 19: Suppl 101: 47-54.

6 Uribe A, Rubio C, Johannsson C. Cell kinetics of rat gastrointestinal mucosa. Autoradiographic study after treatment with 15(R)15-methyl-prostaglandin $\mathrm{E}_{2}$. Scand $J$ Gastroenterol 1986; 21 : 246-52.

7 Dembinski A, Konturek SJ. Effects of E, F and I series prostaglandins and analogues on growth of gastroduodenal mucosa and pancreas. Am J Physiol 1985; 248: G170-5.

8 Fich A, Arber N, Sestieri M, Zajicek G, Rachmilewitz D. Effect of misoprostol and cimetidine on gastric cell labeling index. Gastroenterology 1985; 89: 57-61.

9 Baumgartner A, Weber D, Varga L, Halter F. Comparison of autoradiographic (AR) and Radiochemical (RC) estimation of DNA synthesis in gastric mucosa. Gastroenterology 1986; 90: 1341.

10 Tytgat GNJ, Offerhaus GJA, van Minnen AJ, Everts V, Hensen-Logmans SC, Samson G. Influence of oral 15(R)-15-methyl prostaglandin $\mathrm{E}_{2}$ on human gastric mucosa. Gastroenterology 1986; 90: 1111-20. 